\title{
PENINGKATAN MOTIVASI BERPRESTASI DAN HASIL BELAJAR SISWA PADA TEMA TEMPAT UMUM MELALUI METODE ULAR BERUNTUN
}

\section{Oleh:}

Sutrisno

SDN 4 Ngarho Kedungtuban, Blora

\begin{abstract}
Abstrak
Penelitian ini bertujuan untuk meningkatkan motivasi berprestasi dan hasil belajar siswa dengan menggunakan metode ular beruntun pada tema tempat umum kelas III SDN 4 Ngraho semester I tahun pelajaran 2015/2016.Penelitian ini merupakan penelitian tindakan kelas yang terdiri dari 2 siklus dengan 4 tahapan yaitu perencanaan,tindakan,observasi,dan refleksi.Instrumen yang digunakan dalam pengambilan data adalah berupa tes,observasi dan instrumen kuesioner motivasi berprestasi.Pembelajaran dilakukan dengan dengan menggunakan silabus, rencana pelaksanaan pembelajaran, bahan ajar, dan LKS. Selama penelitian, dilakukanpengamatan keterampilan proses, aktivitas, belajar siswa dan pada akhir pembelajaran dilakukan dengan menggunakan tes untuk mengetahui hasil belajar siswa.Hasil penelitian menunjukan bahwa hasil tes tulis menunjukkan peningkatan . Pra siklus 57 menjadi 66,pada siklus kedua ,meningkat lagi menjadi 87 ,pra sikulus ketuntasan belajar mencapai 35 $\%$ pada siklus 1 mencapai 70,5 \%,pada siklus kedua meningkat menjadi $100 \%$.Hasil pengisian kuesioner mengalami peningkatan dari siklus 1 sampai siklus 2 ,dari $78 \%$ dengan kategori baik meningkat menjadi 96\%dengan kategori sangat baik.Berdasarkan hasil tersebut dapat disimpulkan bahwa dengan menggunakan metode ular beruntun dapat meningkatkan motivasi berprestasi dan hasil belajar siswa.
\end{abstract}

Kata kunci: Motivasi Berprestasi, Hasil Belajar, Tempat Umum, Metode Ular Beruntun

\section{Pendahuluan}

Pembelajaran matematika masih kurang bervariasi dalam menggunakan metode pembelajaran. Di dalam proses pembelajaran, guru hanya menjelaskan materi lalu memberikan contoh soal. Pada kenyataannya timbulah rasa takut pada matematika. Hal ini disebabkan karena siswa kurang hafal perkalian. Siswa juga kurang tertarik terhadap pembelajaran, mereka terlihat terasa jenuh didalam pembelajaran.Pembelajaran juga harus menyenangkan bagi siswa dan pembelajaran matematika menjadi efektif sehingga siswa tidak hanya mampu menghafal konsep matematika, tetapi juga harus dapat diaplikasikan dalam kehidupan sehari-hari, jadi sangat diharapkan dalam proses pembelajaran yang dipraktekkan guru juga melibatkan dan mengaktifkan siswa dalam proses menemukankonsep-konsep matematika. Sehingga pembelajaran matematika di mampu mengembangkan kompetensi- 
kompetensi matematika seperti yang terdapat dalam kurikulum matematika. Siswa kurang termotivasi terkait proses pembelajaran yang monoton (Bowo, \& Novitasari ; 2012).

Untuk itu sebagai seorang guru kita harus mencari dan memilih model, metode dan media pembelajaran yang sesuai dengan apa yang diharapkan.Salah satu metode pembelajaran di Sekolah Dasar yang sesuai dengan pernyataan di atas dan dapat memberikan solusi tentang permasalahan di atas adalah metode ular beruntun. Metode ular beruntun pada pembelajaran matematika adalah cara untuk menyampaikan pelajaran matematika dengan sarana bermain ular-ularan secara berkelompok.Hal ini bertujuan untuk meningkatkan motivasi berprestasi dan hasil belajar siswa dengan menggunakan metode ular beruntun pada tema tempat umum.Manfaat bagi peserta didik yaitu membangkitkan minat belajar dan mengoptimalkan aktivitas siswa sehingga penguasaan kompetensi meningkat dan meningkatkan prestasi dan hasil belajar siswa.Sedangkan untuk manfaat bagi guru dapat memberikan variasi dalam kegiatan belajar mengajar yaitu penerapan metode permainan ular beruntun yang disesuaikan dengan materi pembelajaran dan menambah wawasan guru tentang penggunaaan metode permainan ular beruntun dalam pembelajaran matematika untuk meningkakan motivasi berprestasi dan hasil belajar siswa. Sedangkan manfaat bagi guru adalah dapat memberikan variasi dalam kegiatan belajar mengajar yaitu penerapan metode permainan ular beruntun yang disesuaikan dengan materi pembelajaran dan dapat menambah wawasan guru tentang tentang penggunaaan metode permainan ular beruntun dalam pembelajaran matematika untuk meningkakan motivasi berprestasi dan hasil belajar siswa.

\section{Kajian Teori}

Murray memakai istilah kebutuhan berprestasi (needfor achievement) untuk motivasi berprestasi, yang dideskripsikannya sebagai hasrat atau tendensi untuk mengerjakan sesuatu yang sulit dengan secepat dan sebaik mungkin. (http://staff.Uny.ac.id/sites/ default/files /132319838/motivasi berprestasi). Menurut Murray achievement motivation (motivasi berprestasi) adalah daya penggerak untuk mencapai taraf prestasi belajar yang setinggi mungkin demi pengharapan kepada dirinya sendiri. (http://staff. Uny.ac.id/sites/default/files/ 132319838/motivasi berprestasi). Faktor-faktor yang mempengaruhi motivasi berprestasi belajar yaitu : faktor individu dan faktor lingkungan . yang meliputi adanya norma standar yang harus dicapai,adanya situasi kompetisi dan jenis tugas dan situasi mendatang.

Hasil belajar merupakan bagian terpenting dalam pembelajaran. Nana Sudjana (2009: 3) mendefinisikan hasil belajar siswa pada hakikatnya adalah perubahan tingkah laku sebagai hasil belajar dalam pengertian yang lebih luas mencakup bidang kognitif, afektif, dan 
psikomotorik. Dimyati dan Mudjiono (2006: 3-4) juga menyebutkan hasil belajar merupakan hasil dari suatu interaksi tindak belajar dan tindak mengajar. Dari sisi guru, tindak mengajar diakhiri dengan proses evaluasi hasil belajar. Dari sisi siswa, hasil belajar merupakan berakhirnya pengajaran dari puncak proses belajar. Benjamin S. Bloom (Dimyati dan Mudjiono, 2006: 26-27) menyebutkan enam jenis perilaku ranah kognitif, sebagai berikut:pengetahuan,pemahaman,penerapan,analisis,sintesis dan evaluasi.Faktor - faktor yang mempengaruhi hasil belajar adalah faktor internal yang meliputi : faktor jasmaniah dan faktor psikologis dan faktor ekstrnal yang meliputi :faktor keluarga ,faktor sekolah dan faktor masyarakat .

Dalam metode ini menggunakan metode ular beruntun. Beruntun memiliki arti berurutan, berderet, maksudnya adalah teratur (yang satu setelah yang lain), masuknya harus satu demi satu. Jadi beruntun merupakan peristiwa berurutan, teratur, dimulai dari urutan satu, dua, tiga dan seterusnya ( http: //kbbi.web.id/urut-2). Metode permainan adalah cara mengajar yang dilaksanakan dalam bentuk permainan. Sedangkan metode permainan dalam pembelajaran matematika adalah cara untuk menyampaikan pelajaran matematika dengan sarana bermain. Metode permainan dalam pembelajaran dapat memberikan kesempatan bagi siswa untuk terlibat langsung dalam pembelajaran dan membuat siswa merasa senang terhadap matematika. Metode ular beruntun pada pembelajaran matematika adalah cara untuk menyampaikan pelajaran matematika dengan sarana bermain ular-ularan secara berkelompok. Permainan ular beruntun ini dilakukan diluar kelas. Anak dibagi menjadi 2 - 3 kelompok setiap kelompok terdiri dari sepuluh siswa. Siswa berbaris berbanjar kebelakang. Siswa yang berada didepan merupakan kepala ular yang diberi tanda mahkota ular, siswa yang berada di barisan nomor 2 - 9 merupakan badan ular dan siswa yang berada dibarisan paling belakang merupakan ekor ular.

\section{Metode}

Penelitian ini merupakan penelitian tindakan kelas.Yang dimulai dengan menyusun proposal kegitan PTK, menyusun proposal instrumen penelitian ,pengumpulan data dengan melakukan tindakan siklus 1 dan siklus 2 ,analisis data,pembahasan atau diskusi dan penyusunan laporan penelitian .Data berupa data primer dan data sekunder.Sedangkan teknik dan alat peng meliputi :instrumen berupa tes ,obseravi,kumpulan data dan instrumen kuesioner motivasi berprestasi yaitu dengan cara mengisi angket suatu teknik pengumpulan data secara tidak langsung (peneliti tidak langsung bertanya jawab dengan responden).Validitas data juga meliputi data kuantitatif (berbentuk angka) dan data kualitatif 
(misalnya observasi,dan angket). Analisis data kualitatif pada penelitian ini diperoleh dari hasil observasi yang dilakukan oleh guru dan peneliti yang hasilnya dijadikan sebagai bahan diskusi.

Penelitian ini merupakan antara observer dan digunakan untuk menentukan langkahlangkah kegiatan pembelajaran berikutnya. Hal ini dilakukan sebagai tindak lanjut dalam rangka pencapaian tujuan hasil belajar. Analisis data dalam penelitian kualitatif dilakukan pada saat pengumpulan data berlangsung dan setelah pengumpulan data.

Tabel 1: Kisi-kisi Penyusunan Instrumen Motivasi Berprestasi.

\begin{tabular}{|c|c|c|c|c|c|c|}
\hline \multirow{2}{*}{ Variabel } & \multirow{2}{*}{ Indikator } & \multicolumn{2}{|c|}{ Pernyataan } & \multicolumn{3}{|c|}{ Jumlah Soal } \\
\hline & & Positif & Negatif & + & - & Jml \\
\hline \multirow{7}{*}{$\begin{array}{c}\text { Motivasi } \\
\text { berprestasi }\end{array}$} & a. Berusaha unggul & 1,2 & 3 & 2 & 1 & 3 \\
\hline & $\begin{array}{l}\text { b. Menyelesaikan tugas } \\
\text { dengan baik }\end{array}$ & 4 & 5 & 1 & 1 & 2 \\
\hline & $\begin{array}{l}\text { c. } \begin{array}{l}\text { Rasional dalam meraih } \\
\text { keberhasilan }\end{array} \\
\end{array}$ & 6 & 7 & 1 & 1 & 2 \\
\hline & d. Menyukai tantangan & 8 & 9 & 1 & 1 & 2 \\
\hline & $\begin{array}{l}\text { e. Menerima tanggung jawab } \\
\text { pribadi untuk sukses }\end{array}$ & 10 & 11 & 1 & 1 & 2 \\
\hline & $\begin{array}{l}\text { f. Menyukai situasi belajar } \\
\text { dengan tanggung jawab, } \\
\text { umpan balik dan resiko } \\
\text { tingkat menengah }\end{array}$ & 12 & 13 & 1 & 1 & 2 \\
\hline & Jumlah pernyataan & 7 & 6 & 7 & 6 & 13 \\
\hline
\end{tabular}

Penyelesaian Akhir $=\frac{\text { Total Skor }}{\mathrm{Y}} \times 100$

\section{Hasil dan Pembahasan}

Tabel 2: kegiatan siswa dalam proses pembelajaran dengan menggunakan metode ular beruntun pada siklus I

\begin{tabular}{|c|l|c|c|c|c|}
\hline \multirow{2}{*}{ No } & \multicolumn{2}{|c|}{ Kegiatan yang diamati } & \multicolumn{4}{c|}{ Penilaian } \\
\cline { 2 - 5 } 1 & P1 & P2 & R & Ket \\
\hline \multirow{2}{*}{$\begin{array}{l}\text { Merasa tertarik saat pembelajaran } \\
\text { berlangsung }\end{array}$} & 3 & 3 & 3 & Baik \\
\hline 2 & Mendengarkan penjelasan guru & 3 & 4 & 3,5 & Baik \\
\hline 3 & Mencatat materi yang disampaikan & 2 & 2 & 2 & Kurang \\
\hline 4 & $\begin{array}{l}\text { Mengisi LKS yang diberikan oleh } \\
\text { guru }\end{array}$ & 4 & 4 & 4 & Baik Sekali \\
\hline 5 & Menjawab pertanyaan dari guru & 3 & 3 & 3 & Baik \\
\hline 6 & Mengerjakan evaluasi & 3 & 4 & 3,5 & Baik \\
\hline & Jumlah & & & 19 & \\
\hline & Skor Maksimal & & & 24 & \\
\hline & Persentase (\%) & & & \\
\hline
\end{tabular}


Tabel 3 : kegiatan siswa dalam proses pembelajaran dengan menggunakan metode ular beruntun pada siklus II

\begin{tabular}{|c|l|c|c|c|c|}
\hline \multirow{2}{*}{ No } & \multicolumn{2}{|c|}{ Kegiatan yang diamati } & \multicolumn{4}{|c|}{ Penilaian } \\
\cline { 3 - 6 } & \multicolumn{1}{|c|}{ P1 } & P2 & $\mathbf{R}$ & Ket \\
\hline 1 & $\begin{array}{l}\text { Merasa tertarik saat pembelajaran } \\
\text { berlangsung }\end{array}$ & 3 & 4 & 3,5 & Baik \\
\hline 2 & Mendengarkan penjelasan guru & 4 & 3 & 3,5 & Baik \\
\hline 3 & Mencatat materi yang disampaikan & 3 & 4 & 3,5 & Baik \\
\hline 4 & $\begin{array}{l}\text { Mengisi LKS yang diberikan oleh } \\
\text { guru }\end{array}$ & 4 & 4 & 4 & Baik sekali \\
\hline 5 & Menjawab pertanyaan dari guru & 3 & 3 & 3 & Baik \\
\hline 6 & Mengerjakan evaluasi & 4 & 4 & 4 & Baik sekali \\
\hline & Jumlah & & & 21,5 & \\
\hline & Skor Maksimal & & & 89,6 & \\
\hline & Persentase (\%) & & & 24 & \\
\hline
\end{tabular}

Sehingga dapat disimpulkan bahwa kegiatan siswa pada pembelajaran mengalami peningkatan dari siklus I ke siklus II. Dari angka 79,2\% meningkat menjadi 89,6\%.

Tabel 4 :Rekapitulasi hasil belajar siklus I

\begin{tabular}{|l|l|l|l|l|l|l|}
\hline No & Kategori & Rentang nilai & F & Bobot & Persentease & Ket \\
\hline 1 & Sangat baik & $90-100$ & 2 & 190 & $11,7 \%$ & $\begin{array}{l}\text { Rata-rata } \\
1130 / 17=66 \\
\text { Ketuntasan klasikal } \\
12 \text { atau } 12 / 17 \times 100 \%\end{array}$ \\
\hline 2 & Baik & $70-89$ & 4 & 310 & $18,2 \%$ & \\
\hline 3 & Cukup & $60-69$ & 6 & 370 & $21,7 \%$ & \\
\hline 4 & Kurang & $0-59$ & 5 & 260 & $15,29 \%$ & \\
\cline { 1 - 4 } Jumlah & & 17 & 1130 & $100 \%$ & \\
\hline
\end{tabular}

Ketuntasan : jika siswa yang mendapat nilai lebih dari atau sama dengan 65 mencapai 80\%

Tabel 5: Rekapitulasi hasil belajar siklus II

\begin{tabular}{|c|c|c|c|c|c|c|}
\hline No & Kategori & Rentang nilai & $\mathrm{F}$ & Bobot & Persentease & Ket \\
\hline 1 & $\begin{array}{l}\text { Sangat } \\
\text { baik }\end{array}$ & $90-100$ & 6 & 580 & $34,12 \%$ & \multirow{5}{*}{$\begin{array}{l}\text { Rata-rata } \\
1475 / 17=87 \\
\text { tuntasan klasikal } 17 \\
\text { atau } 17 / 17 \times 100 \%\end{array}$} \\
\hline 2 & Baik & $70-89$ & 8 & 700 & $41,17 \%$ & \\
\hline 3 & Cukup & $60-69$ & 3 & 195 & $11,47 \%$ & \\
\hline 4 & Kurang & $0-59$ & 0 & 0 & $15,29 \%$ & \\
\hline \multicolumn{2}{|c|}{ Jumlah } & & 17 & 1475 & $100 \%$ & \\
\hline
\end{tabular}

Ketuntasan :jika siswa yang mendapat nilai lebih dari atau sama dengan 65 mencapai 80\%.Sehingga dapat disimpulkan bahwa kegiatan rekapitulasihsil belajar siswa pada pembelajaran mengalami peningkatan dari siklus I ke siklus II. Dari angka 65 meningkat menjadi 87. 


\section{Data Hasil Kuesioner}

A. Rangkuman hasil penilaian panelis untuk pertanyaan positif dan negatif pada siklus 1

1. Panelis untuk pertanyaan positif siklus 1 : panelis yang menjawab selalu $($ skor $=4)$ berjumlah 48 jadi $48 \times 4=192$, panelis yang menjawab sering (skor $=3$ ) berjumlah 38 jadi 34 x $3=102$, panelis yang menjawab kadang-kadang (skor $=2$ ) berjumlah 20 jadi 20 x 2 = 40 dan yang menjawab tidak pernah (skor $=1$ ) berjumlah 11 jadi 15 x $1=15$.

2. Panelis untuk pertanyaan negatif siklus 1 : panelis yang menjawab selalu $($ skor $=1$ ) berjumlah 10 jadi $10 \times 1=10$, panelis yang menjawab sering $($ skor $=2)$ berjumlah 10 jadi 10 x $2=20$, panelis yang menjawab kadang-kadang (skor =3) berjumlah 19 jadi 16x $3=48$ dan panelis yang menjawab tidak pernah (skor $=4$ ) berjumlah 66 jadi $66 x 4=280$ Penyelesaian akhir $=$ Total Skor x $100:$ skor tertinggi $=691 \times 100: 884=78 \%$.

Hasil pengisian kuesioner di siklus I ini menunjukkan angka 78\% dengan kategori baik, tetapi hasil ini belum memenuhi indikator keberhasilan sebesar $80 \%$.

B. Rangkuman hasil penilaian panelis untuk pertanyaan positif dan negatif pada siklus 2

1. Panelisuntuk pertanyaan positif siklus 2 :panelis yang menjawab selalu $($ skor $=4)$ berjumlah 111 jadi 98x $4=392$,panelis yang menjawab sering (skor = 3) berjumlah 18jadi 18 x $3=54$, panelis yang menjawab kadang-kadang (skor $=2$ ) berjumlah 2 jadi $2 \times$ $2=4$ dan panelis yang menjawab tidak pernah (skor $=1$ ) berjumlah 0 jadi $0 \times 1=0$.

2. Panelis untuk pertanyaan negatif siklus 2 :panelis yang menjawab selalu $($ skor $=1)$ berjumlah 0 jadi $0 \times 1=0$,panelis yang menjawab sering $($ skor $=2)$ berjumlah 1 jadi $1 \mathrm{x}$ $2=2$ panelis yang menjawab kadang-kadang (skor $=3$ ) berjumlah 15 jadi 8 x $3=24$, panelis yang menjawab tidak pernah (skor $=4$ ) berjumlah 98 jadi $94 \mathrm{x} 4=376$. Penyelesaian akhir $=$ Total Skor $\times 100:$ skor tertinggi $=852 \times 100: 884=96 \%$

Hasil pengisian kuesioner di siklus I ini menunjukkan angka 96\% dengan kategori baik, tetapi hasil ini sudah memenuhi indikator keberhasilan sebesar $80 \%$.

\section{Simpulan dan Saran}

Berdasarkan rumusan masalah hasil penelitian dan pembahasan dalam penelitian tindakan kelas dengan penggunanan model pembelajaran ular beruntun ini dapat disimpulkan sebagai berikut:

1. Hasil observasi kegiatan siswa pada siklus I mencapai $79,2 \%$, ternyata pada siklus I hasilnya belum mencapai harapan yaitu sama dengan atau lebih dari $80 \%$. Proses belajar 
mengajar pada siklus II ini berlangsung dengan baik. Hal ini dapat dibuktikan pada hasil observasi kegiatan siswa yang mengalami peningkatan dengan hasil 89,6\%.

2. Hasil tes tulis menunjukkan peningkatan Pra siklus rata-rata 57,siklus I meningkat menjadi rata-rata 66 dan pada siklus II meningkat lagi menjadi 87,pra siklus ketuntasan belajar mencapai 35\% dan pada siklus I mencapai 70,5 \% , pada siklus II peningkataan persentase ketuntasan belajar dari 70,5\% meningkat menjadi $100 \%$.

3. Hasil pengisian kuesioner pun mengalami peningkatan dari siklus I sampai siklus II, dari 78\% dengan kategori baik meningkat menjadi 96\% dengan kategori sangat baik. Dengan demikian metode ular beruntun dapat meningkatkan motivasi berprestasi dan hasil belajar siswa pada tema tempat umum kelas III SDN 4 Ngraho Tahun 2015/2016.

Adapun saran yang dapat penulis sampaikan berkaitan dengan penelitian ini adalah sebagai berikut :

1. Sebaiknya guru menggunakan metode yangbervariasi dalam kegiatan belajar mengajar, salah satunya dengan menggunakan metode ular beruntun yang disesuaikan dengan materi pembelajaran.

2. Sebaiknya pembelajaran jangan selalu dilakukan di dalam kelas, karena akan membuat siswa cepat bosan dan jenuh. Alangkah baiknya sesekali siswa diajak belajar keluar kelas tentunya juga disesuaikan dengan materi pembelajaran

\section{Daftar Pustaka}

Ari Bowo, A., \& Novitasari, N. (2012). PENINGKATKAN MOTIVASI BELAJAR MELALUI STRATEGI READING GUIDE KOLABORASI INDEX CARD MATCH DALAM PROSESPEMBELAJARAN PKn SISWA SMP. Academy of $\begin{array}{llll}\text { Education Journal, } & \text { 3(2). from }\end{array}$ https://jurnal.ucy.ac.id/index.php/fkip/article/view/90

Dimyati dan Mudjiono. 2006. Belajar dan Pembelajaran. Jakarta: Rineka Cipta.

Kurnia, H. (2014). PENGARUH KEAKTIFAN BERORGANISASI TERHADAP INDEKS PRESTASI KUMULATIF MAHASISWA UNIVERSITASCOKROAMINOTO YOGYAKARTA. Academy of Education Journal, 5(2). Retrieved from https://jurnal.ucy.ac.id/index.php/fkip/article/view/120

Sudjana, Nana. 2009. Penilaian Hasil Proses Belajar Mengajar. Bandung: PT. Remaja Rosda Karya.

http://staff.Uny.ac.id/sites/default/files/132319838/motivasi berprestasi.(12/8/2015.08:10) 
Arikunto, Suharsimi. 2006. Prosedur Penelitian suatu pendekatan praktek. Jakarta: Rineka Cipta.

Arikunto, Suharsimi, dkk. 2006. Penelitian Tindakan Kelas. Jakarta: Bumi Aksara.

Arikunto, Suharsimi. 2004. Evaluasi Program Pendidikan. Jakarta: Bumi Aksara.

Aqib, Zaenal. 2006. Penelitian Tindakan Kelas. Bandung: CV. Yrama Widya.

Baharudin dan Esa Nur Wahyuni. 2007. Teori Belajar Dan Pembelajaran. Jogjakarta:Ar-ruzz Media.

Dimyati dan Mudjiono. 2006. Belajar dan Pembelajaran. Jakarta: Rineka Cipta.

Gatot Muhsetyo, dkk. 2012. Pembelajaran Matematika SD. Tangerang Selatan:Universitas Terbuka.

Sudijono, Anas. 2003. Pengantar Statistik Pendidikan. Jakarta: Rajawali Pers.

Sudjana, Nana. 2009. Penilaian Hasil Proses Belajar Mengajar. Bandung: PT. Remaja Rosda Karya.

Sugihartono, dkk. 2007. Psikologi Pendidikan. Yogyakarta: Uny press.

Wardani, dkk. 2013. Pemantapan Kemampuan Profesional.Tangerang Selatan: Universitas Terbuka.

Rositawaty,S,dkk:2008. Sain untuk Sekolah Dasar Kelas III.Jakarta:Pusat Perbukuan

Buchori,2008. Cerdas Berhitung Matematika untuk Kelas 3.Jakarta:Pusat Perbukuan

Prayoga,Bestari.2008. Pendidikan Kewarganegaraan untuk SD Kelas III.Jakarta:PT. Gelora Aksara Pratama 